Nalar: Jurnal Peradaban dan Pemikiran Islam

Vol. 3, No. 1, Juni 2019

\title{
Konsep Bimbingan dan Konseling Pribadi-Sosial dalam Pengembangan Positive Mental Attitude Generasi Z
}

\author{
Iin Handayani
}

Mahasiswa Pascasarjana Universitas Islam Negeri Sunan Kalijaga Yogyakarta iinhandayani618@gmail.com

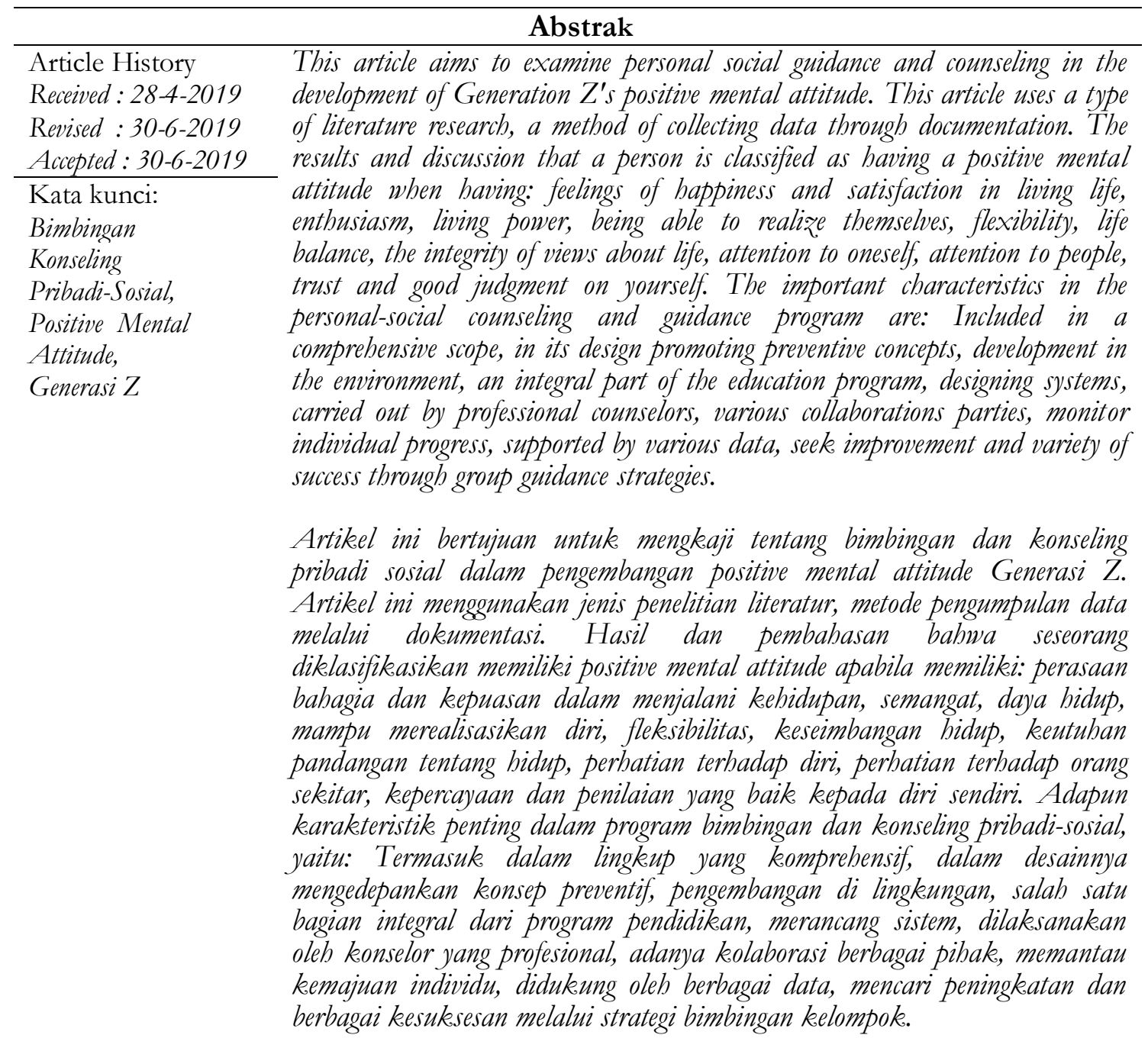

\section{Pendahuluan}

Kebutuhan akan adanya bimbingan dan konseling dalam kehidupan individu dan masyarakat sangat diperlukan untuk mencapai perkembangan yang sehat dalam lingkungannya. Bimbingan dan konseling umumnya bertujuan membantu seseorang, baik individu maupun kelompok untuk menginternalisasi, memelihara dan memaknai nilai dalam kehidupan sebagai acuan atau landasan bagi pengembangan diri seseorang. Batasan atau definisi tentang bimbingan dan konseling merupakan suatu hal yang sulit untuk digeneralisasi, karena para ahli memiliki sudut pandang yang berbeda-beda tergantung dari segi mana ia melihatnya.

Berikut penulis akan menyajikan beberapa pandangan menurut para ahli. Menurut Dewa Ketut Sukardi (1983:65) menyatakan bahwa bimbingan adalah suatu proses 
Nalar: Jurnal Peradaban dan Pemikiran Islam

Vol. 3, No. 1, Juni 2019

pemberian bantuan kepada individu agar ia mampu mengembangkan potensi yang dimilikinya seperti bakat, minat dan skill. Konsep tersebut mengenai dirinya sendiri dan cara mengatasi permasalahan agar mereka dapat memilih jalan hidupnya sendiri serta memiliki tanggung jawab tanpa bergantung kepada orang lain disekitarnya. Muhammad Surya menambahkan dalam Sukardi (2000:20) bahwa bimbingan merupakan proses bantuan yang diberikan secara terus menerus dan sistematis dari seorang pembimbing agar yang dibimbing mampu mencapai kemandirian dalam memahami dirinya sendiri untuk mengelola peningkatan perkembangan yang optimal dan penyesuaian diri dengan lingkungan dimana ia berada.

Sehubungan dengan hal tersebut, Prayitno dan Erman Amti mengutip pernyataan Maclean, Sherzer dan Stone (2015:100) yang menyatakan bahwa konseling ialah proses terjadinya face to face (tatap muka) antara individu yang mengalami gangguan karena permasalahan yang tidak mampu diatasi sendiri dengan melibatkan seorang konselor yang profesional, dalam hal ini seorang yang telah mengikuti pelatihan khusus dan pengalamannya membantu orang lain dalam mencapai suatu pemecahan terhadap kesulitan pribadi yang dialami. Oleh karena itu, Arifin (2000:12) menyatakan perihal mengenai bimbingan konseling yang menurutnya hal tersebut merupakan keseluruhan kegiatan yang dialami oleh seseorang dalam prosesnya memberikan bantuan terhadap orang lain yang memiliki kesulitan dalam lingkungannya, agar individu tersebut mampu mengatasi permasalahannya karena adanya suatu kesadaran atau bentuk penyerahan diri terhadap keEsaan Tuhan sehingga timbul pada dirinya suatu harapan yang menuntunnya untuk dapat hidup bahagia saat sekarang dan di masa yang akan datang.

Dalam artikel ini akan dibahas mengenai bimbingan dan konseling pribadi sosial. Bimbingan dan konseling pribadi sosial menurut Nurihsan (2006:15) merupakan bimbingan untuk membantu individu menyelesaikan masalah-masalah pribadi-sosialnya. Bentuk layanan bimbingan dan konseling harus dilandasi oleh penguasaan kompetensi akademik dan kompetensi professional konselor. Paradigma pembahasan yang digunakan dalam artikel ini mengacu pada layanan bimbingan dan konseling pribadi sosial dalam pengembangan positive mental attitude Generasi $Z$ yang memandang manusia dari perspektif kelebihannya, bukan dari kekurangannya.

Menurut Sanburnd dalam penelitian Subandowo (2017:197) penamaan pada generasi-generasi awalnya terlahir dari generation theory (teori generasi) yang muncul dan bermula di Amerika, khusunya Amerika Serikat. Pencetus teori generasi ini menarik kesimpulan pemahaman berupa pengelompokan berbagai generasi yang didasarkan pada tahun kelahirannya. Jumlah Generasi $\mathrm{Z}$ diseluruh dunia berdasarkan data yang diunduh UN World Population Estimate (2015) bahwa kurang lebih 2,5 miliar jumlah jiwa (34,05\%) dan berdasarkan Indonesia-Sensus (2010) sekitar 68,02 juta jiwa (28,86\%). Menurut Tapscott (2013:18-39) membagi demografi penduduk Amerika ke dalam beberapa kelompok generasi sebagai berikut:

a. Kelompok generasi yang lahir antara tahun 1946-1964 atau sering disebut dengan istilah The Baby Boom

b. Kelompok generasi yang lahir antara tahun 1965-1976 atau sering disebut dengan istilah The Baby Bust

c. Kelompok generasi yang lahir antara tahun 1977-1997 atau sering disebut dengan istilah The Millennial

d. Kelompok generasi yang lahir antara tahun1998 hingga kini, atau sering disebut dengan istilah Generation Net (Generasi Z).

Djiwandono dalam penelitian Susana (2012:62) mengemukakan bahwa generasi Z memiliki gaya yang cenderung selalu belajar untuk aktif, general, sensing dan secara visual. Generasi $Z$ yang aktif maksudnya mudah mempelajari sesuatu dengan mempraktikkan sendiri apa yang ingin dipelajarinya. General berarti seorang individu yang biasanya belajar dengan cara melompat dari materi satu ke materi yang lain, kemudian menyerap materi tersebut secara random tanpa memerhatikan keterkaitannya satu sama lain dan mendapatkan sesuatu yang diinginkan secara tiba-tiba. Hal tersebut sama dengan 
Nalar: Jurnal Peradaban dan Pemikiran Islam

Vol. 3, No. 1, Juni 2019

pembelajar yang global dimana ia mampu mengatasi permasalahan yang kompleks secara cepat dengan merangkai segala sesuatunya menjadi cara baru ketika mereka dapat melihat gambaran umumnya. Hal tersebut menyebabkan anak Generasi Z tidak sabar untuk menunggu proses. Mereka selalu mengandalkan jawaban dari setiap pertanyaan dan tantangan hidup dari informasi-informasi yang ada diinternet. Mereka tidak mengetahui bahwa persoalan hidup tidak semua bisa diatasi dan dipecahkan melalui kecanggihan teknologi.

Beberapa permasalahan dalam kehidupan harus diselesaikan dengan proses yang lumayan panjang dari dirinya sendiri, baik itu melalui cara renungan, usaha fisik, usaha psikis dan juga memerlukan bantuan orang lain secara langsung, bukan secara virtual. Salah satu bantuan tersebut dapat melalui bimbingan dan konseling pribadi sosial. Sebagaimana dalam buku Mochamad Nursalim (2015: 17) bahwa bimbingan konseling pribadi sosial merupakan layanan yang ditujukan membantu seseorang agar individu tersebut mampu menemukan dan menunjukkan progres dirinya sendiri sebagai pribadi yang memiliki iman dan ketakwaan terhadap Tuhan, berusaha mandiri dan memantapkan diri, sehat secara jasmani maupun rohani, bisa mengenal dan berinteraksi dengan lingkungan sosialnya secara bertanggung jawab. Dengan demikian, penelitian ini akan berfokus pada peran bimbingan dan konseling khususnya BK pribadi-sosial yang dituntut untuk mampu menjawab berbagai problematika Generasi Z di era kekinian melalui pengembangan positive mental attitude. Adapun cakupan yang akan dibahas terkait Generasi Z, positive mental attitude yang harus dimiliki Generasi Z, hubungan antara bimbingan konseling pribadi-sosial dan problematika Generasi Z.

Jenis penelitian dalam artikel ini menggunakan studi kepustakaan (literatur) yang dilakukan dengan cara mengkaji teori-teori dan praksis melalui kepustakaan baik itu dari jurnal ilmiah, internet, buku, e-book, dan fakta-fakta yang ada di lapangan khususnya mengenai Generasi Z. Metode pengumpulan data yang digunakan melalui dokumentasi dengan teknik analisis menggunakan reduksi data yaitu proses pemusatan perhatian atau pemilihan untuk mengabstrakkan, menyederhanakan dan mentransformasi data yang masih bersifat kasar, disusun secara sistematis dengan menonjolkan pokok-pokok penting agar pembaca lebih mudah paham, hingga kemudian ditarik suatu kesimpulan dan diverifikasi. Hasil dari berbagai telaah literatur ini akan digunakan untuk mengidentifikasi layanan BK pribadi-sosial dalam upaya pengembangan positive mental attitude Generasi Z.

\section{Pembahasan}

Gagasan yang ditawarkan dalam karya ilmiah ini adalah bentuk layanan bimbingan konseling pribadi sosial sebagai upaya pengembangan positive mental attitude Generasi Z. Namun, sebelum lebih jauh membahas tentang hal tersebut, penulis merasa perlu menjelaskan mengenai bimbingan dan konseling pribadi-sosial terlebih dahulu.

Menurut Abu Ahmadi dalam penelitian Emmi Kholilah Harahap (2015:286) bimbingan pribadi sosial yang dimaksud adalah suatu usaha berupa bantuan yang diberikan kepada individu agar dapat mengahadapi dan menyelesaikan sendiri masalah-masalah pribadi sosialnya dengan mengadakan penyesuaian baik dalam lingkup pribadi maupun sosial, memilih dan memilah kelompok sosialnya, memilih berbagai kegiatan sosial dan kegiatan rekreatif yang bernilai dan berguna, serta berupaya memecahkan masalahnya sendiri baik itu pribadi dan sosialnya.

Sejalan dengan pernyataan tersebut, Nurihsan (2006:15) mengemukakan bahwa bimbingan pribadi-sosial adalah bimbingan untuk membantu seseorang atau sekelompok orang dalam proses menyelesaikan masalah pribadi sosialnya. Masalah-masalah pribadi sosial dalam hal ini yaitu hubungannya dengan orang tua, keluarga, dosen, teman, tetangga, sifat dan kemampuan dirinya, penyesuaian diri dengan lingkungannya baik dalam ranah pendidikan maupun dalam lingkungan masyarakat tempat tinggalnya, serta penyelesaian konflik yang dihadapi.

Berdasarkan pengertian tersebut di atas, dapat dipahami bahwa bimbingan pribadisosial yang dimaksud yaitu bimbingan dan pengarahan yang diberikan seorang ahli kepada 
Nalar: Jurnal Peradaban dan Pemikiran Islam

Vol. 3, No. 1, Juni 2019

seorang individu atau suatu kelompok dalam menghadapi, memecahkan dan menyelesaikan masalah pribadi sosialnya, seperti konflik pribadi dan penyesuaian diri agar sikap-sikap mental positif dapat tertanam dalam dirinya sebagai pribadi yang memiliki tingkat keimanan dan ketakwaan kepada penciptanya, yang senantiasa berusaha sehat dari segi jasmani dan rohaninya agar mampu mengenal dan bersosialisasi dengan lingkunganya secara bertanggungjawab.

Menurut Norman C. Gysbreg dalam penelitian Caraka Putra Bhakti (2015:101) bahwa: Researh has demonsrated that, when middle school counselor have time, the structure of comprehensive guidance program in wich to work, they contribute to positive academic, personal-social and career development as well as the development positive and safe learning climates in school.

Yunita Dwi Setyoningsih (2018:143) mengemukakan bahwa dalam IOWA Konseling Komprehensif dan Bimbingan Pengembangan Program menetapkan domain standar kurikulum perkembangan mengenai pribadi sosial seseorang sebagai berikut:

a. Siswa mampu memperoleh suatu pengetahuan, keterampilan interpersonal dan sikap yang baik dalam rangka membantu individu atau kelompok memahami serta menghargai diri sendiri dan orang lain.

b. Siswa mampu membuat suatu keputusan bagi dirinya sendiri, menentukan tujuan hidupnya dan berusaha memilih langkah-langkah yang diperlukan untuk mencapai tujuan hidup yang telah direncanakan.

c. Siswa dapat paham mengenai keterampilan dirinya untuk dapat bertahan hidup.

Penelitian Caraka Putra Bhakti dan Nindiya Eka Safitri (2017:110-111) merumuskan beberapa layanan bimbingan dan konseling pribadi-sosial yang dapat dilaksanakan yaitu:

a. Layanan BK pribadi-sosial diadakan untuk memberi motivasi sukses kepada para generasi $\mathrm{Z}$ sehingga mereka dapat memiliki masa depan dalam hal studi dan karir yang baik. Layanan yang diberikan dalam konteks ini bisa berupa layanan pengembangan bakat dan minat, peminatan tentang studi lanjut, diperlukan pula kolaborasi lembaga kerja dengan sekolah untuk memberikan wawasan mengenai karir sesuai dengan keahlian dan potensi siswa.

b. BK pribadi-sosial memanfaatkan Information Technology (IT) dan komunikasi serta media lain yang dapat memudahkan siswa mengakses konten seperti gambar, audio, video, film, educative games, macromedia flash dan lain sebagainya.

c. BK dalam pelayanannya berfokus pada pengembangan keterampilan dalam pemecahan masalah, pengembangan kepercayaan diri, pengembangan keterampilan berpikir kritis dan selalu inovatif. Penyelenggaraan layanan berupa layanan bimbingan klasikal, bimbingan kelompok menggunakan teknik diskusi atau dalam hal ini lebih dikenal dengan istilah Focus Group Disscusion (FGD), simulation games dan problem solving. Pada layanan yang bersifat kuratif, guru BK melakukan sistem e-counseling agar siswa bisa memanfaatkan layanan BK yang tersedia dengan konsep yang sebaik-baiknya tanpa harus face to face dengan guru BK. Contohnya dengan menggunakan aplikasi Twitter, Facebook, Instagram, Whats App, Telegram dan lain sebagainya.

d. Guru BK dalam memberi layanan dalam konteks ini bisa menggunakan sarana yang mendukung dan disukai oleh siswa, seperti LCD proyektor, laptop yang terkoneksi internet, MP3/MP4 player dan sebagainya.

Bower dan Hatch dalam penelitian Hardi Santosa (2013:5-6) menyatakan berbagai karakteristik mengenai program bimbingan konseling komprehensif yang setidaknya sejalan dengan program BK pribadi-sosial, yaitu:

a. Comprehensive in scope

Karakteristik utama mengenai program bimbingan dan konseling yaitu comphrehensive in scope artinya bahwa program yang dilaksanakan harusnya memiliki cakupan yang komprehensif. Program tersebut ditujukan untuk seluruh siswa sebagai upaya dalam membantu mereka sebagai klien menempuh tingkat keberhasilan bukan hanya pada bidang pribadi-sosial namun juga menyangkut bidang akademik dan karir. Sehingga hal tersebut mampu menjadikan seseorang sebagai pribadi yang senantiasa bernilai bagi masyarakat. 
Nalar: Jurnal Peradaban dan Pemikiran Islam

Vol. 3, No. 1, Juni 2019

\section{b. Preventive in design}

Program ini dirancang untuk memberi kesempatan peserta didik dalam membekali diri mereka melalui berbagai keterampilan khusus, membantu peserta didik untuk mencapai keberhasilan melalui pengalaman dan perkembangan pada bidang pribadi-sosial, akademik, karir. Selain itu, siswa diharapakan mampu memnfaatkan kesempatan belajar yang dimiliki secara aktif dan produktif.

\section{c. Developmental in nature}

Guru bimbingan dan konseling atau konselor dalam arti luas merancang berbagai program dan berupaya memberikan layanan yang baik sebagai pemenuhan atas kebutuhan peserta didik yang tidak dapat dipungkiri memiliki berbagai variasi tahap perkembangan dan pertumbuhannya.

d. Integral part of the total educational program

Program bimbingan konseling dalam hal ini menjadi satu bagian yang tidak dapat terpisah dari semua program pendidikan dalam usahanya membantu peserta didik menghadapi berbagai tantangan, belajar memahami dan memenuhi tuntutan pendidikan yang sebenarnya. Hal ini umumnya berjalan beriringan dengan program administrasi dan pengajaran di sekolah.

e. Design a delivery sistem

Delivery sistem menggambarkan berbagai macam kegiatan, proses belajar dan wilayah lain yang dilakukan konselor dalam menyampaikan dan melaksanakan program. Dalam implementasi program konselor menggunakan empat komponen program yang sudah diatur waktu dan porsi masing masing dari setiap komponen tersebut. Empat komponen program itu adalah layanan dasar, layanan responsive, layanan perencanaan individual dan dukungan sistem.

\section{f. Implemented by a state-cridentialed school counselor}

Program bimbingan dan konseling dalam hal ini tidak dapat dilakukan oleh sembarangan orang, apalagi ada guru yang tidak berlatarbelakang pendidikan dan tidak memahami konsep dari bimbingan dan konseling itu sendiri. Oleh karena itu, program bimbingan dan konseling sudah seharusnya dilaksanakan oleh guru BK atau konselor yang professional dan memiliki kredensiliasi.

g. Conducted in collaboration

Pelaksanaan program bimbingan dan konseling berkolaborasi dengan berbagai pihak. Baik itu orang tua, wali kelas, staf administrasi, guru mata pelajaran, anggota masyarakat dan para professional lain yang dapat membantu jalannya suatu bimbingan.

h. Monitor student progress

Program ini dirancang agar guru BK atau konselor dapat memantau perkembangan dan kemajuan prestasi yang dicapai oleh siswa. Konselor dalam hal ini diharapkan dapat konsisten dalam membantu peserta didik yang biasanya ada kasus yang berkelanjutan. Guru BK juga membantu perencanan studi lanjut dan karir peserta didik dengan meminimalisir hambatan yang mereka hadapi.

\section{i. Driven by data}

Bimbingan dan konseling dalam hal ini setiap programnya harus dibuat berdasarkan data-data yang faktual terpercaya, bisa diperoleh dari need assessment seluruh peserta didik. Dengan demikian, data yang actual, factual dan akurat dapat memberikan gambaran mengenai apa yang dibutuhkan peserta didik sehingga dapat menyajikan berbagai cara yang bisa dipertanggungjawabkan untuk disesuaikan dengan visi dan misi suatu instansi.

\section{j. Seeks improvement}

Program bimbingan konseling ini dirancang, diarahkan dan diberikan penerangan menuju pengembangan dan peningkatan yang signifikan. Hal itu bisa dilakukan setelah mengetahui hasil evaluasi terhadap suatu program. Evaluasi program dilakukan dengan tujuan agar dapat mengetahui keefektifan dan pengaruhnya pada peserta didik. Isi dari evaluasi program ini mencakup evaluasi proses dan hasil akhir. Kemudian hasil evaluasi program ini dirancang untuk membentuk program baru melalui berbagai penyesuaian.

k. Share successes 
Nalar: Jurnal Peradaban dan Pemikiran Islam

Vol. 3, No. 1, Juni 2019

Rancangan program bimbingan dan konseling bertujuan agar siswa bisa saling berbagi informasi terkait dengan keberhasilan yang diperoleh. Program bimbingan ini memberikan sebuah kesempatan kepada guru BK selaku konselor sekolah, orang tua, pihak sekolah dan stakeholders untuk mengetahui keberhasilan yang telah digapai oleh siswa dari hasil pelaksanaan melalui berbagai program bimbingan dan konseling yang dilaksanakan di sekolah.

Sementara menurut Mochamad Nursalim (2015:12-13) bahwa strategi pelaksanaan program BK pribadi-sosial untuk masing-masing komponen pelayanan adalah:

a. Pelayanan dasar, merupakan layanan yang bersifat umum ditujukan bagi siswa secara keseluruhan. Layanan ini terstruktur dan mengarah pada pengembangan kompetensi yang harus dikuasai oleh seluruh siswa. Strategi yang digunakan bisa berupa bimbingan kelompok, bimbingan klasikal, kolaborasi guru bidang studi dan adanya proses kerja sama dengan masing-masing orang tua siswa. Contoh materinya mencakup harga diri, motivasi berprestasi, keterampilan komunikasi, keefektivan dalam hubungan antar pribadi dan sebagainya.

b. Pelayanan responsif, adalah suatu layanan yang difokuskan untuk memberikan bantuan atau mengintervensi seluruh siswa dalam upaya mengatasi berbagai permasalahan yang dihadapinya. Hal ini bersifat penanganan krisis, remediatif dan preventif. Strategi pemberian layanannya berupa konsultasi individual atau kelompok, referal atau lebih dikenal dengan istilah alih tangan kasus, kolaborasi dengan wali kelas dan guru mata pelajaran, kolaborasi dengan orang tua atau pihak keluarga yang terkait, adanya bantuan dan bimbingan teman sebaya, konferensi kasus dan home visit.

c. Perencanaan individual, yaitu layanan untuk membantu siswa mengembangkan dan mengimplementasikan rencana pribadi sosial. Tujuannya membantu mengidentifikasi dan melihat secara jelas pertumbuhan dan perkembangan siswa secara proaktif agar bisa membuat rencana, memantau dan mengelola rencana studi, dunia kerja dan tujuan jangka pendek maupun panjang mereka sendiri. Adapun strateginya yaitu mencetuskan tujuan, melakukan kegiatan yang sesuai dengan tujuan dan mengevaluasi kegiatan yang pernah dilakukan.

d. Adanya dukungan dengan sistem, hal yang dimaksud adalah berbagai komponen yang menyangkut aspek manajerial termasuk pengembangan program, alokasi dana dan fasilitas, kolaborasi orang tua dan sumber lain, pengembangan staf, penelitian dan pengembangan. Layanannya berupa pengembangan profesi dan manajemen program.

Setelah pembahasan bimbingan dan konseling pribadi sosial di atas, berikut akan dijelaskan mengenai Generasi Z. Menurut Tapscott dalam penelitian Teguh Dwi Putranto (2018:19) bahwa Generasi Z adalah generasi teknologi. Mereka telah mengenal media sosial sejak dini atau dalam hal ini Generasi Z tumbuh di dunia yang hampir keseluruhan kehidupannya terhubung dengan teknologi sejak lahir. Generasi ini disebut generasi internet karena mereka tumbuh di era digital yang akhirnya membuat mereka mampu mengakses informasi dengan cepat meski diusia yang masih sangat muda. Generasi ini sangat sering berkomunikasi dengan semua kelompok, terutama jaringan sosial seperti facebook, twitter, instagram, Whats App dll. Mereka biasanya peka dan toleran terhadap budaya yang berbeda dan sangat memperdulikan lingkungan. Sejalan dengan pernyataan tersebut, berdasarkan hasil penelitian Caraka Putra Bhakti dan Nindiya Eka Safitri (2017:108) dalam kehidupan Generasi Z mempunyai nilai Plus dan nilai Minus di masyarakat yaitu:

a. Nilai Plus

Generasi Z memiliki sikap ingin tahu yang sangat tinggi. Mereka tidak perlu diajari ketika dihadapkan dengan berbagai teknologi canggih karena dengan sendirinya generasi ini berupaya agar mereka dapat menguasai apa yang menjadi kebutuhan dan apa yang harus dilakukan untuk bisa mengaplikasikan dan mempraktikkan gejala yang muncul pada suatu teknologi. Hal lain yang merupakan sifat yang tidak terpisahkan dari Generasi Z adalah multitasking, mengerjakan berbagai aktivitas dalam waktu yang sama, misalnya bisa membaca chat, sambil berbicara via telepon, kemudian menonton atau bisa jadi mendengarkan musik. 
Nalar: Jurnal Peradaban dan Pemikiran Islam

Vol. 3, No. 1, Juni 2019

Sudah disinggung sebelumnya bahwa Generasi $\mathrm{Z}$ mempunyai kepedulian tinggi terhadap lingkungan dan politik, sehingga apabila generasi ini mendapatkan pendidikan yang baik dan layak maka mereka kelak akan sangat bermanfaat bagi diri dan lingkungan untuk menciptakan generasi-generasi yang berdaya saing tinggi.

b. Nilai Minus

Generasi Z memiliki nilai minus yang cenderung tidak sabar, terburu-buru ingin menyelesaikan permasalahan dengan menggunakan cara yang instan karena telah terbiasa melakukan komunikasi dan berinteraksi melalui media sosial yang cenderung lebih cepat dan bersifat praktis. Beberapa dari kalangan generasi $Z$ juga kurang terampil dalam melakukan komunikasi verbal yang bisa saja menyebabkan dirinya untuk tidak peduli dengan lingkungannya.

Setelah melihat beberapa hasil penelitian di atas, maka disimpulkan bahwa Generasi $\mathrm{Z}$ ialah generasi pascamilenial, mereka lahir di era digital yang merupakan kelompok manusia termuda di dunia saat ini, dimana gaya hidup telah banyak dipengaruhi oleh IT dan gaya komunikasi yang telah berkembang pesat. Generasi $\mathrm{Z}$ memiliki daya adopsi pengetahun yang tinggi, menghargai keberagaman, multitasking, namun cenderung ketergantungan pada kegiatan dan aktivitas di media sosial.

Berdasar dari fenomena tersebut, konselor disarankan untuk mampu memberikan adopsi mengenai pengembangan positive mental attitude terhadap penyesuaian diri Generasi Z. Attitude tersebut adalah sikap seseorang yang konotasinya berarah kepada sifat positif. Mar'at mengemukakan (1981:17) bahwa sikap yang ditunjukkan seseorang lebih dipandang sebagai suatu hasil belajar dibandingkan sebagai suatu hasil yang dikembangkan ataupun sesuatu yang menurutnya diturunkan. Mengenai sikap sebagai suatu hasil dari proses belajar bahwa sikap yang sudah melekat tersebut masih dapat diubah, diperbaiki atau kembali seperti semula walau prosesnya perlu menggunakan waktu cukup lama. Berdasarkan hal tersebut, maka sebenarnya sikap adalah produk yang muncul dari hasil sosialisasi dan interaksi seseorang yang sifatnya humanistik, dalam hal ini kebebasan individu bisa ditentukan melalui kondisi lingkungan sekitar yang berlaku. Sedangkan menurut Koentjaraningrat (1985:26) bahwa attitude merupakan sikap yang mengarah pada mental dalam jiwa dan diri seseorang. Biasanya sikap dipengaruhi oleh nilai budaya sehingga konsep-konsep tersebut menjadi akar dalam jiwanya yang sukar berubah dalam waktu relatif singkat.

Ahmad Rusydi (2012:11) dalam penelitiannya menyatakan bahwa Islam itu sangat penting karena mencakup perilaku batin seseorang. Misalnya konsep sebuah niat, konsep keikhlasan, dan yang terpenting adalah keridhaan dari suatu perilaku yang bukan hanya perbuatan fisiknya yang ditampakkan, namun lebih dari itu perilaku terhadap batin yang ada di dalamnya. Berdasarkan penilaian psikologisnya, perilaku dalam hal ini tentang batin merupakan suatu perilaku yang pengaruhnya besar terhadap keadaan dan kondisi mental individu dimana hal tersebut memengaruhi pola perilaku yang ditampakkan seseorang. Individu yang selalu menanamkan prasangka baik kepada sesamanya dan kepada penciptanya ialah orang yang berada pada suatu kondisi kejiwaan yang tenang atau biasa disebut al-nafs al-muthmainnah, ia selalu merasakan ketenangan dan mencoba untuk selalu berserah diri kepada Tuhan atas apa yang mungkin bisa terjadi pada dirinya, dalam hal ini penyerahan diri kepada Tuhan bukan berarti suatu hal yang sifatnya pesimis, akan tetapi penyerahan diri karena ia sepenuhnya meyakini akan hubungan mereka yang dekat dengan Tuhan. Maka penelitian ini mencoba untuk melihat pengembangan positive mental attitude yang tujuannya supaya individu-individu bisa merasakan kedekatan dan senantiasa bermusyahadat dengan penciptanya dengan rutin.

Sehingga diharapkan positive mental attitude tersebut akan menghadirkan sisi dari suatu hal baik mengenai apapun yang akan terjadi pada dirinya sehingga ia dapat menghilangkan perasan negatif yang melekat, menghilangkan perasaan akan kekalahan dan menghilangkan rasa putus asa. Dengan istilah lain bahwa orang yang memiliki metal positif menstimulus dengan baik segala situasi dan kondisi di dalam kehidupannya. Menurut Baumgardner \& Crother (2010) bahwa mental yang positif memberi kontribusi kepada peningkatan 
Nalar: Jurnal Peradaban dan Pemikiran Islam

Vol. 3, No. 1, Juni 2019

kebahagiaan subjektif dalam diri seseorang, berhubungan dengan harapan hidup yang lebih lama, kemungkinan tertular penyakit yang lebih rendah dan kesembuhan (recovery) yang lebih baik apabila seseorang mengalami suatu keadaan sakit.

Hardi Prasetiawan (2016:55) dalam penelitiannya mencetuskan bahwa ada tiga metode efektif untuk membentuk positive mental attitude di lingkungan keluarga yaitu:

a. Melalui metode keteladanan, orang tua menjadikan dirinya sebagai teladan atau contoh yang baik bagi anaknya dalam semua hal. Misalnya senantiasa menanamkan sifat kejujuran, memiliki sikap yang dermawan, senantiasa beribadah, menolong orang lain dll.

b. Metode pembiasaan, merupakan proses seseorang bertingkahlaku baik yang telah dicontohkan oleh orang tua dengan mengulang terus menerus. Sebaiknya orang tua membuat jadwal aktivitas dan kegiatan untuk anak-anak mereka dari pagi hari sampai malam hari dengan menyelipkan dan berusaha memberikan pemahaman tentang moral, etika, sopan santun, dan berbagai kebiasaan baik lainnya.

c. Memberikan rewards atau penghargaan sebagai respon atas perilaku baik seorang anak.

Hanurawan (2012:3) juga mengungkapkan bahwa secara umum terdapat beberapa

ciri seseorang dapat diklasifikasikan sebagai orang yang memiliki positive mental attitude, yaitu:

a. Seseorang memiliki perasaan bahagia dan kepuasan dalam menjalani kehidupan.

b. Seseorang memiliki semangat dalam menjalani kehidupan (kemampuan untuk menikmati hidup, keceriaan, dan kesenangan-kesenangan yang lain).

c. Seseorang memiliki daya hidup (elan vital) dalam menghadapi stres hidup dan bangkit dari kegagalan-kegagalan hidup yang dialami.

d. Seseorang memiliki kemampuan untuk merealisasikan diri. Kemampuan realisasi diri adalah kemampuan berpartisipasi dalam hidup sesuai dengan potensi-potensi terbaik yang ada dalam dirinya melalui aktivitas-aktivitas hidup yang bermakna dan hubungan sosial yang positif.

e. Seseorang memiliki kemampuan fleksibilitas. Kemampuan fleksibilitas adalah kemampuan untuk berubah, berkembang, dan mengalami berbagai variasi perasaan sejalan dengan variasi perubahan kondisi kehidupan.

f. Seseorang memiliki perasaan tentang keseimbangan hidup (keseimbangan privasi dan sosialitas, bermain dan bekerja, tidur dan bangun, serta istirahat dan beraktivitas).

g. Seseorang memiliki perasaan tentang keutuhan pandangan tentang hidup (wellroundedness) yang meliputi pandangan tentang roh, jiwa, tubuh, kreativitas dan perkembangan intelektual.

h. Seseorang memiliki perhatian kepada diri sendiri dan orang lain.

i. Seseorang memiliki kepercayaan diri dan penilaian diri yang baik kepada diri sendiri.

Dalam penelitiannya Hanurawan (2012:4) juga mengemukakan rumusan Myers, Sweeney, dan Witmer terhadap model sikap mental yang positif bahwa orang yang memiliki kesehatan mental yang positif adalah yang mampu memenuhi lima tugas dan dua belas sub tugas dalam segenap aktivitas hidupnya. Lima tugas itu adalah memahami esensi spiritualitas, keseimbangan antara berkerja dan memanfaatkan waktu luang, mengembangkan persahabatan, mengembangkan cinta, dan mandiri. Dan dua belas sub tugas yang dimaksud adalah memiliki perasaan berarti kepada diri sendiri, memiliki perasaan kontrol, memiliki keyakinan yang bersifat realistis, kesadaran emosi dan koping, pemecahan masalah dan kreativitas, memiliki perasaan humor, memperoleh nutrisi yang cukup, melakukan olahraga, memiliki perhatian kepada diri sendiri, memiliki kemampuan untuk mengelola stres, memiliki kesadaran tentang identitas gender dan memiliki kesadaran tentang identitas budaya.

Berdasar pada pengertian dan karakteristik positive mental attitude di atas, maka dalam bidang pendidikan dan sosial seorang pendidik maupun konselor memiliki kewajiban untuk mengembangkan positive mental attitude itu pada Generasi Z. Pentingnya pengembangan mental itu berdasar rasional bahwa kesehatan mental manusia tidak dapat dilepaskan dari keseluruhan aspek kehidupan manusia. 
Nalar: Jurnal Peradaban dan Pemikiran Islam

Vol. 3, No. 1, Juni 2019

Dalam hal ini, apabila mengalami stres maka kesehatan fisik seseorang juga akan terpengaruh. Banyak permasalahan mengenai kesehatan fisik yang disebabkan karena stres sebagai suatu wujud dari gangguan yang terjadi pada mental individu dan untuk kasus tertentu bahkan menyebabkan penyakit seperti serangan jantung, stroke, bahkan kesehatan fisiknya bisa sampai tidak bisa seimbang lagi. Kondisi fisik dan kondisi mental yang tidak sehat dapat memberikan dampak atau pengaruh yang buruk terhadap aspek dalam kehidupan sosial dan kehidupan kerja individu itu sendiri.

Data yang ditemukan bahwa konselor sebagai seorang pendidik yang profesional dapat memberikan layanan bimbingan konseling sebagai upaya dalam proses didikan untuk membantu seseorang dalam pengembangan dirinya secara aktif dan optimal sesuai dengan tahapan perkembangan serta tuntutan lingkungan yang berpengaruh sebagaimana yang termaktub dalan UU RI No 14 tahun 2005 pada pasal 7 tentang Guru dan Dosen bahwa jati diri konselor sebagai profesi adalah melakukan pelayanan ahli terhadap bidang bimbingan dan konseling dalam setting pedagogis, bukan hanya memberi pelayanan konseling tetapi juga berbagai layanan bimbingan seperti aspek pribadi, belajar, sosial dan karir yang menempatkan pelayananan konseling sebagai suatu ikon layanan bimbingan konseling yang sifatnya memandirikan klien pada jalur pendidikan yang bersifat formal (DEPDIKNAS, 2007; ABKIN, 2008). Avin Fadilla Helmi (2012:111) menyatakan bahwa fenomena yang menarik pada kehidupan suatu masyarakat adalah maraknya global culture dan life style. Era global terhadap informasi dibarengi dengan perkembangan daring dari berbagai media sosial. Misalnya instagram, facebook, twitter dan Whats App yang pada saat sekarang banyak digunakan dalam membantu beberapa kegiatan mengenai akses suatu informasi dan menunjukan eksistensinya tanpa ada batas ruang, waktu, biaya, usia, budaya, suku dan agama.

Berdasarkan hasil survey Cengage Learning pada penelitian Zadrian Ardi, Indah Sukmawati (2017:30) mengungkapkan bahwa lebih dari 59\% pelajar mengakses media sosial pada saat pembelajaran berlangsung, sehingga hal ini berakibat pada tidak fokusnya siswa mengikuti pembelajaran, kurangnya partisipasi dalam kegiatan diskusi, kurang fokus dalam pengerjaan tugas dan terganggunya proses transfer dalam pembelajaran kepada siswa. Kondisi adiktif lain yang berpengaruh pada kesehatan mental individu, khususnya pada subjective well being adalah ketergantungan pada kegiatan dan aktivitas di media sosial.

Kenyataan - kenyataan tersebut menuntut konselor untuk tanggap terhadap perkembangan IT dan berbagai kasus yang muncul. Konselor diharapkan juga mempunyai berbagai pengetahuan, wawasan, sikap dan nilai yang bisa dijadikan sebagai referensi yang tepat dan baik dalam sebuah penanganan terhadap klien dalam hubungannya mengenai kasus berkenaan dengan pengaruh IT tersebut.

Sebagaimana fungsi BK yang dimaksud dalam penelitian Sutijono dan Farid (2018:21) ialah fungsi penyesuaian, pemahaman, penyaluran, fasilitasi, adaptasi, pencegahan, penyembuhan, perbaikan, pemeliharaan dan pengembangan. Perkembangan IT yang semakin hari semakin pesat bisa digunakan untuk menunjang kegiatan dan aktivitas pelayanan yang dilakukan konselor pada individu-individu, seperti halnya penanaman sikap mental positif, yang dapat digunakan sebagai salah satu solusi. Mochamad Nursalim (2015:9) mengatakan bahwa dalam bimbingan konseling di Indonesia sejalan dengan apa yang terdapat dalam KTSP atau Panduan Pengembangan Diri Kurikulum Tingkat Satuan Pendidikan, ada empat bidang perkembangan yang menjadi sasaran khusus bagi pelayanan bimbingan dan konseling yaitu bidang bimbingan akademik, bimbingan karir, bimbingan pribadi dan bimbingan sosial sebagaimana yang telah dijelaskan juga sebelumnya.

Berdasarkan pernyataan di atas, maka dalam penelitian ini strategi yang dipakai dalam pelaksanaan layanan pada setiap program bimbingan dan konseling pribadi-sosial bertujuan mengembangkan positive mental attitude Generasi Z melalui strategi powering of community atau kekuatan bimbingan kelompok. Dasar pertimbangannya karena salah satu tujuan dari bimbingan kelompok yaitu untuk menciptakan ruang pemahaman terhadap diri dan orang lain serta menginginkan adanya perubahan terhadap perilaku yang lebih baik. Bukan hanya itu, adapun fungsi dari bimbingan kelompok yang dimaksud dalam penelitian 
Nalar: Jurnal Peradaban dan Pemikiran Islam

Vol. 3, No. 1, Juni 2019

adalah untuk mencegah datang dan berkembangnya masalah pribadi-sosial dalam diri seseorang.

Konteks bimbingan dan konseling pribadi-sosial ini juga menekankan terselenggaranya kolaborasi antar sesama guru BK dengan memberikan ruang juga kepada stakeholder sekolah maupun orang tua di rumah untuk menyelenggarakan layanan BK. Perkembangan siswa terjadi karena diikuti oleh perubahan perilaku pada dirinya, seperti perilaku kognitif, psikomotorik, keagamaan, perilaku sosial dan perilaku moralitas.

Dengan demikian, positive mental attitude harus tumbuh pada diri setiap individu karena itu akan membantu menentukan bagaimana individu bertingkah laku. Adapun hasil yang diharapkan setelah terselenggaranya kegiatan bimbingan pribadi-sosial sebagai upaya pencegahan terjadinya perilaku yang tidak semestinya adalah Generasi Z bisa paham tentang pentingnya nilai dan moral yang berlaku di masyarakat serta memiliki keterampilan berfikir kritis supaya individu selalu siap siaga dalam menghadapi pengaruh negatif yang mungkin muncul dari berbagai segi baik dari informasi teknologi dan komunikasi maupun lingkungan sosialnya yang lain.

\section{Penutup}

Gagasan yang ditawarkan penelitian literatur ini ialah pemberian layanan bimbingan dan konseling pribadi sosial dalam upayanya terhadap pengembangan positive mental attitude untuk menghadapi Generasi Z. Sebagaimana diketahui bahwa positive mental attitude memberi kontribusi kepada peningkatan kebahagiaan subjektif dalam diri seseorang, berhubungan dengan harapan hidup yang lebih lama, kemungkinan tertular penyakit yang lebih rendah dan recovery yang lebih baik apabila seseorang mengalami suatu keadaan sakit.

Seseorang dapat diklasifikasikan sebagai orang yang memiliki positive mental attitude apabila: memiliki perasaan bahagia dan kepuasan dalam menjalani kehidupan, memiliki semangat dalam menjalani kehidupan, memiliki daya hidup (elan vital), memiliki kemampuan untuk merealisasikan diri, memiliki kemampuan fleksibilitas, memiliki perasaan tentang keseimbangan hidup, memiliki perasaan tentang keutuhan pandangan tentang hidup (wellroundedness), memiliki perhatian kepada dirinya dan orang disekitarnya, memiliki kepercayaan diri dan penilaian yang baik kepada diri sendiri.

Adapun kegiatan yang dilaksanakan dalam proses pengembangan terhadap berbagai program bimbingan dan konseling pribadi sosial mencakup tentang perancangan, perencanaan, penerapan dan evaluasinya. Dalam hal ini, terdapat komponen atau karakteristik penting dalam menjalankan program bimbingan konseling pribadi-sosial, yakni comprehensive in scope, preventive in design, developmental in nature, integral part of the total educational program, design a delivery sistem, implemented by a state-cridentialed school counselor, conducted in collaboration, monitor student progress, driven by data, seeks improvement, and share successes.

Strategi yang dipakai dalam proses pelayanan program bimbingan dan konseling pribadi-sosial memiliki tujuan untuk mengembangkan sikap mental positif Generasi Z melalui strategi kekuatan bimbingan kelompok. Sebagai dasar pertimbangan, karena dalam hal ini salah satu tujuan kegiatan bimbingan kelompok yaitu menanamkan pemahaman terhadap diri dan orang lain serta diharapkannya perubahan perilaku setelah mengikuti proses bimbingan dan konseling. Selain itu, adapun fungsi dari bimbingan kelompok ini menekankan untuk seseorang dapat mencegah timbulnya permasalahan yang baru baik dari pribadi maupun sosialnya.

Konteks bimbingan dan konseling pribadi-sosial ini juga menekankan adanya kerjasama antara guru Bimbingan dan Konseling dengan stakebolder yang ada di sekolah maupun orang tua di rumah untuk menjalankan layanan BK yang diharapkan. Perkembangan siswa terjadi karena diikuti oleh perubahan pada diri, seperti psikomotorik, perilaku sosial, perilaku kognitif, moralitas dan perilaku keagamaannya.

Perkembangan IT yang makin pesat bisa dipakai untuk menunjang kegiatan dan aktivitas layanan yang diberikan oleh konselor terhadap individu-individu, seperti halnya penanaman sikap mental positif, yang dapat digunakan sebagai salah satu solusi. Penulis 
Nalar: Jurnal Peradaban dan Pemikiran Islam

Vol. 3, No. 1, Juni 2019

berupaya memberikan sebuah paradigma berfikir yang bersifat spesifik ditujukan kepada konselor dan profesi helper lainnya dalam seting konseling.

Penulis berharap konselor dapat mengimplementasikan layanan BK pribadi-sosial dengan menyesuaikan layanan sesuai perkembangan zaman. Konselor dalam hal ini, diharapkan peka terhadap perkembangan IT. Dan bagi Generasi Z, kiranya penting untuk lebih peka mengendepankan positive mental attitude terhadap dinamika perubahan dalam konteks kemasyarakatan. Selain itu, akan lebih baiknya jika penelitian ini bisa dikembangkan menjadi penelitian lapangan agar implementasi dari teori yang telah dirumuskan dapat diterapkan secara jelas melihat berbagai fenomena terkait gaya hidup Generasi Z. 
Nalar: Jurnal Peradaban dan Pemikiran Islam

Vol. 3, No. 1, Juni 2019

\section{Daftar Pustaka}

ABKIN. (2008). Krisis Identitas Profesi Bimbingan dan Konseling.

Ardi, Zadrian. Indah Sukmawati. (2017). Social Media And The Quality Of Subjective Well-Being; Counseling Perspective In Digital Era (Proceedings | Ices 2017 International Counseling And Education Seminar The Responsibility Of Counselor And Educator In Millennium Era.

Arifin. 2000. Bimbingan Penyuluhan Islam. Jakarta: Bina Aksara.

Baumgardner, S.R. \& Crother, M.K. (2010). Positive Psychology. Upper Saddle River, New Jersey: Pearson Education Inc.

Bhakti, Caraka Putra. (2015). Bimbingan dan Konseling Komprehensif: Dari Paradigm Menuju Aksi. Jurnal Fokus Konseling. Vol. 1 No. 2.

Bhakti, Caraka Putra., Nindiya Eka Safitri. (2017). Peran Bimbingan dan Konseling untuk Menghadapi Generasi Z dalam Perpektif Bimbingan dan Konseling Perkembangan, Jurnal Konseling Gusjijang Vol. 3 No. 1.

Departemen Pendidikan Nasional. (2007). Undang-Undang SISDIKNAS (Sistem Pendidikan Nasional) UU RI No. 20 tahun 2003 dan Undang-Undang Guru dan Dosen UU RI No. 14 tahun 2005. Jakarta.

Hanurawan, Fattah. (2012). Strategi Pengembangan Kesehatan Mental di Lingkungan Sekolah, PSIKOPEDAGOGIA, Vol. 1, No. 1.

Harahap, Emmi Kholilah. (2015). Layanan Bimbingan dan Konseling Pribadi Sosial dalam Meningkatkan Keterampilan Hubungan Sosial Siswa. TAJDID. Vol. XIV, No. 2.

Helmi, Avin Fadilla. Yopina Galih Pertiwi. (2012). Psikologi untuk Kesejahteraan Masyarakat. Yogyakarta: Pustaka Pelajar.

Koentjaningrat.(1985) Pengantar Ilmu Antropologi. Jakarta: Aksara Baru.

Mar'at. (1981). Sikap Manusia Perubahan Serta Pengukurannya. Jakarta Timur: Ghalia Indonesia.

Nurihsan, A. J. (2006). Bimbingan dan Konseling dalam Berbagai Latar Kehidupan. Bandung: Refikaaditama.

Nursalim, Mochamad. (2015). Bimbingan dan Konseling Pribadi-Sosial. Yogyakarta: Ladang Kata.

Prasetiawan, Hardi. (2016). Peran Bimbingan dan Konseling dalam Pendidikan Rahmat Anak terhadap Pembentukan Karakter Sejak Usia Dini. Jurnal CARE (Children Advisory Research And Education), Vol. 04, No. 1.

Prayitno. Erman Amti. 2015. Dasar-Dasar Bimbingan dan Konseling. Cet. III; Jakarta: Rineka Cipta.

Putranto, Teguh Dwi (2018). Kelas Sosial dan Perempuan Generasi Z di Surabaya dalam Membuat Keputusan Setelah Lulus Sekolah Menengah Atas. Jurnal Komunikasi Profesional. Vol. 2, No. 1.

Rusydi, Ahmad. (2012). Husn Al-Zhann: Konsep Berpikir Positif dalam Perspektif Psikologi Islam dan Manfaatnya bagi Kesehatan Mental. Proyeksi. Vol. 7, No. 1.

Santosa, Hardi. (2013). Program Bimbingan dan Konseling Pribadi Sosial untuk Mengembangkan Perilaku Seksual Sehat Remaja (Studi Pengembangan di SMA Kartika Siliwangi 1 Bandung, Psikopedagonia Jurnal Bimbingan dan Konseling. Vo. 2. No. 1.

Setyoningsih, Yunita Dwi. (2018). Tantangan Konselor di Era Milenial dalam Mencegah Degradasi Moral Remaja, Prosiding SNBK (Seminar Nasional Bimbingan dan Konseling). Vol. 2, No. 1.

Subandowo, M. (2017). Peradaban dan Produktivitas dalam Perspektif Bonus Demografi Generasi Y dan Z. Jurnal Pendidikan Sains Sosial dan Kemanusiaan. Vol. 10, No. 2.

Sukardi, Dewa Ketut. 1983. Dasar-Dasar Bimbingan Penyuluhan di Sekolah. Surabaya: Usaha Nasional.

Sukardi, Dewa Ketut. 2000. Bimbingan dan Konseling di Sekolah. Jakarta: Rineka Cipta. 
Nalar: Jurnal Peradaban dan Pemikiran Islam

Vol. 3, No. 1, Juni 2019

Susana, Tjipto. (2012). Kesetiaan pada Panggilan di Era Digital. Jurnal Orientasi Baru. Vol. 21. No. 1.

Sutijono \& Dimas Ardika Miftah Farid (2018). Cyber Counseling di Era Generasi Milenial. Sosiohumanika: Jurnal Pendidikan Sains Sosial dan Kemanusiaan. Vol. 11, No.1.

Tapscott, Don, (2013). Grown Up Digital. Jakarta: Gramedia Pustaka Utama. 